\title{
Somatotropic gene response to recombinant growth hormone treatment in buffalo leucocytes
}

\author{
Lorenzo Castigliego ${ }^{1, *}$, Xiao-Ning $\mathrm{Li}^{2}$, \\ Andrea Armani ${ }^{1}$, Maria Razzano ${ }^{3}$, Marco Mazzi ${ }^{3}$, \\ Remo Rosati ${ }^{4}$, Daniela Gianfaldoni ${ }^{1}$ and \\ Alessandra Guidi ${ }^{1}$ \\ ${ }^{1}$ Department of Animal Pathology, Prophylaxis and Food \\ Hygiene, University of Pisa, Via delle Piagge 2, I-56124 \\ Pisa, Italy \\ ${ }^{2}$ Department of Animal Science and Technology, \\ University of Guangxi, Daxue Road 100, Nanning \\ 530005, People's Republic of China \\ ${ }^{3}$ Animal Production Research Centre (PCM), Agriculture \\ Research Council (CRA), Via Salaria, 31, I-00015 \\ Monterotondo, Rome, Italy \\ ${ }^{4}$ Experimental Zooprophylactic Institute of Lazio and \\ Tuscany, Via Appia Nuova 1411, I-00178 Rome, Italy \\ *Corresponding author \\ e-mail: lcastigl@vet.unipi.it
}

\begin{abstract}
The use of recombinant bovine growth hormone (rbGH) to increase milk yield in cows is banned in some countries. In others, where it is authorised, it has triggered harsh debates on labelling of dairy products. If many studies have been performed on bovines, there is a lack of information on buffaloes, which are sometimes treated with $\mathrm{rbGH}$ and represent an important economical resource for dairy products in some countries. Analytical methods with legal value for surveillance of rbGH treatments do not yet exist. Research on gene expression biomarkers is one of the most promising approaches to this purpose. For this reason, we treated five buffaloes for 10 weeks with a sustained-release formulation of rbGH and analysed the response of 20 somatotropic axis genes in leucocytes by real-time polymerase chain reaction. Overall changes in gene expression levels were of low magnitude and sometimes affected by the 'time' factor. Only the IGFBP-1 gene showed a significant under-expression (about two-fold; $p<0.001$ ) in treated animals. Taken together, these results give evidence that expression analysis of the somatotropic axis genes in leucocytes is little helpful for discrimination of rbGH-treated buffaloes, but do not exclude that another array of genes could provide useful patterns of variation.
\end{abstract}

Keywords: biomarkers; buffalo; gene expression analysis; real-time PCR; recombinant bovine growth hormone.

\section{Introduction}

Growth hormone $(\mathrm{GH})$ is a peptide hormone produced in vertebrates by the pituitary gland, which is responsible for a number of anabolic processes affecting body growth and tissue metabolism.

$\mathrm{GH}$ action can be direct or mediated by other molecules, among which the most important is insulin-like growth factor-1 (IGF-1). GH-induced effects are the result of a complex net of interactions, known as the somatotropic axis, which primarily involves other hormones (IGFs), their binding proteins (IGFBPs) and their receptors (Renaville et al., 2002).

Involvement of the somatotropic axis in the regulation of lactation has been demonstrated by several studies performed on many animal species. In particular, it has been clearly shown that administration of exogenous GH induces a significant increase in milk yield (McGuire et al., 1992). GH stimulus to lactation has been exploited by some pharmaceutical companies, which, using recombinant DNA techniques, have created a number of recombinant bovine growth hormones (rbGH) to be used for zootechnical purposes (Bauman, 1992). Treatment with rbGH has been successfully applied to cows for many years, and it is employed nowadays in a few countries. Administration of rbGH has been demonstrated to be effective also on buffaloes, which constitute an important economical resource for dairy production in some areas of the world (Helal and Lasheen, 2008). Besides the authorised use of rbGH in livestock, an illegal use of this hormone also occurs in some countries where it has been banned, both in bovines and in buffaloes. For this reason, analytical methods able to reveal rbGH treatments would be recommended to support controls not only in countries where this hormone is forbidden, but also in countries where it is allowed, in order to verify compliance in labelling, where contemplated.

Research for setting up analytical methods to reveal rbGH treatments has been partially successful, mainly due to the high level of identity between the recombinant and the pituitary forms of the hormone. At present, the most fruitful results have been obtained by complex techniques, such as mass spectrometry (Le Breton et al., 2009). Difficulties in direct analytical approaches are stimulating a growing consideration for indirect approaches, aimed at revealing potential biomarkers for rbGH treatment.

The most studied candidate marker has been IGF-1, whose concentration increases in blood and milk after treatment (Daxenberger et al., 1998; Castigliego et al., 2011). Even though this occurrence may represent an indicator, it cannot be used for unequivocal yes/no responses on the eventual rbGH treatments. Other studies have focussed on the alteration of expression of a number of genes in some organs, such as the muscle in bovines (Castigliego et al., 2010a). Some researches have also successfully detected exogenous GH-dependent effects on gene expression in human (Mitchell 
et al., 2009; Fernández-Pérez et al., 2010) and rat (Qin and Tian, 2010) leucocytes, which constitute a substrate that is easy to collect and whose physiology is modulated at various levels by GH (Jeay et al., 2002; Chung et al., 2009; Chen et al., 2010). Furthermore, searching for gene expression biomarkers has also provided promising results for other categories of anabolic agents (Riedmaier et al., 2009).

In this study, we examined the effect of rbGH administration on the expression of genes involved in the somatotropic axis regulation in leucocytes of buffaloes treated for a period of 10 weeks, by applying a relatively simple method of screening based on real-time polymerase chain reaction (PCR).

Results made it possible to evaluate their potentiality as biomarkers and to obtain some information on somatotropic axis gene behaviour after GH overstimulation.

\section{Results}

\section{Milk yield, serum hormones and leucocyte count}

During the period of the study, milk yield increased by an average of $32 \%$. Serum GH and IGF-1 concentrations increased significantly in treated animals $(p<0.001)$, showing the effectiveness of rbGH treatment. In brief, $\mathrm{GH}$ serum concentration was $<2 \mathrm{ng} / \mathrm{ml}$ before treatment in both groups of animals and increased up to $60 \mathrm{ng} / \mathrm{ml}$, on an average, in treated animals on day 2 after $\mathrm{GH}$ administration. On day 9, serum GH values returned to basal levels (Castigliego et al., 2011).

The haematocrit and leucocyte counts; number of lymphocytes and monocytes; and number of neutrophil, eosinophil and basophil granulocytes ranged in physiological values (unpublished data). No significant differences were observed between treated and non-treated buffaloes.

\section{Gene response to treatment}

Sequencing of the amplified DNA revealed homology ranging from $98 \%$ to $100 \%$ with the deposited sequences (Table 1).

GHR variants $1 \mathrm{~A}, 1 \mathrm{~F}, 1 \mathrm{G}$ and $1 \mathrm{H}$ were excluded from analysis since no expression was detected in samples coming from the treated animals and the controls during the first cycle of injection. Variant $1 \mathrm{E}$ was also not further considered because it could never be amplified with an acceptable threshold cycle $(\mathrm{Ct})$, nor in leucocytes or in other tissues, although different couples of primers were tried. Furthermore, IGFBP-5 was found to be expressed at a very low level and in a discontinuous manner. Therefore, values obtained for this gene were not considered sufficiently reliable to be included in the statistical analysis.

Comparison between the rbGH-treated buffaloes and the controls, for each gene analysed over the whole period of experimentation, is reported in Figure 1 and Table 2. rbGH administration did not have a marked effect on somatotropic genes. Only IGFBP-1 expression levels were significantly increased, both on day $2(p<0.001)$ and on day $14(p<0.01)$, while the time effect was significant on many genes, whose levels of expression were not found to be constant during the five cycles of treatment. This was particularly evident for variant $1 \mathrm{~B}, I G F-2, I G F-1 R, I G F B P-4$ and $I G F B P-6$, as shown in Table 2. This trend was also observed in the nontreated animals, as revealed by the Friedman's test on basal value variations. Treatment-time interaction effect was never significant. With regard to the paired comparison between day 2 and day 14 of each single gene, significant differences were observed only for variant $1 \mathrm{C} 1$ and for $I G F-2$, whose levels of expression were found to be lower at the end of the bi-weekly cycles than at the beginning. No differences were observed in the non-treated group.

Correlations between the expression of different genes are reported in Tables 3 and 4 .

As for the absolute level of expression, IGF-2 mRNA abundance was much higher than IGF-1 mRNA, whose related $\mathrm{Ct}$ values were at the borderline of exclusion from the analysis (Figure 2). The IGFBP-related gene with the highest expression level was IGFBP-2. IGFBP-1, -4 and -6 were expressed with an apparent lower level and a comparable intensity. IGFBP-3 was the less expressed gene. With regard to the receptors, $I G F-1 R$ was noticeably more expressed than $G H R$. However, when the expression level of the GHR coding region (cds-GHR) was compared with that of GHR $5^{\prime}$ untranslated region $\left(5^{\prime}\right.$-UTR) variants, it was observed that the former seemed less expressed than the latter, especially when matched with variant I, whose level of expression exceeded several times that of cds-GHR, as well as those of other variants. Variant $1 \mathrm{D}$, although still detectable, showed very low expression levels, while the mRNA of the other variants was more abundant.

\section{Discussion}

\section{Choice of the biological target and of the reference genes}

Because this investigation was mainly aimed at testing the potential power of gene expression variation as a biomarker for rbGH treatment, white blood cells were chosen for the simplicity and limited invasiveness of sample collection, with respect to other tissues. This makes this biological substrate a good candidate for control analysis. Substantial evidence in humans show that GH is an important modulator of the immune system (Jeay et al., 2002; Welniak et al., 2002). Phagocytic functions of neutrophils and monocytes are impaired in GH-deficient subjects and improved after GH replacement therapy (Manfredi et al., 1994). The natural killer activity of lymphocytes is reduced in the GH-deficient state and recovered by GH treatment, which also protects lymphocytes against apoptosis induced by glucocorticoids (Jeay et al., 2002). Recently, it was also shown that GH influences haematopoiesis and the numbers of white blood cells (Chen et al., 2010). This last effect was not observed in this study. The influence of GH on leucocytes has also been demonstrated by 
Table 1 Primer sequence, GenBank accession number (or reference) and amplicon length for every gene analysed in this study.

\begin{tabular}{|c|c|c|c|c|}
\hline $\begin{array}{l}\text { Gene or mRNA } \\
\text { variant }\end{array}$ & & Primer sequence & $\begin{array}{c}\text { GenBank accession no./ } \\
\text { Reference }\end{array}$ & $\begin{array}{l}\text { Amplicon } \\
\text { length (bp) }\end{array}$ \\
\hline \multirow[t]{2}{*}{$H M B S$} & $\mathrm{f}$ & CTT TGG AGA GGA ATG AAG TGG & Pérez et al. (2008) & 80 \\
\hline & $\mathrm{r}$ & AAT GGT GAA GCC AGG AGG AA & & \\
\hline \multirow[t]{2}{*}{ EEFIA2 } & $\mathrm{f}$ & GCA GCC ATT GTG GAG ATG & Pérez et al. (2008) & 196 \\
\hline & $\mathrm{r}$ & ACT TGC CCG CCT TCT GTG & & \\
\hline \multirow[t]{2}{*}{$S F 3 A 1$} & $\mathrm{f}$ & GCG GGA GGA AGA AGT AGG AG & Pérez et al. (2008) & 125 \\
\hline & $\mathrm{r}$ & TCA GCA AGA GGG ACA CAA A & & \\
\hline \multirow[t]{2}{*}{$I G F-1$} & $\mathrm{f}$ & TGC TCT CCA GTT CGT GTG & GQ301206.1 & 142 \\
\hline & $\mathrm{r}$ & CAT CTC CAG CСТ CСТ CAG & & \\
\hline \multirow[t]{2}{*}{$I G F-2$} & $\mathrm{f}$ & ACA GTT TGT CTG TGG GGA C & E01192-FJ032306 & 164 \\
\hline & $\mathrm{r}$ & TCA CAT CCC TCT CGG ACT TG & & \\
\hline \multirow[t]{2}{*}{$I G F B P-1$} & $\mathrm{f}$ & CGT CAA GAA GTG GAA GGA G & NM174554 & 193 \\
\hline & $\mathrm{r}$ & GTA GAC ACA CCA ACA GAG C & & \\
\hline \multirow[t]{2}{*}{$I G F B P-2$} & $\mathrm{f}$ & AAG GTC ACG GAG CAG CAC & NM174555-DQ079594 & 197 \\
\hline & $\mathrm{r}$ & GGG ATG TGT AGG GAG TAG AGG & & \\
\hline \multirow[t]{2}{*}{$I G F B P-3$} & $\mathrm{f}$ & CTA CGA GTC TCA GAG CAC AG & AF305712-AY338972 & 103 \\
\hline & $\mathrm{r}$ & GTG GTT CAG CGT GTC TTC C & & \\
\hline \multirow[t]{2}{*}{$I G F B P-4$} & $\mathrm{f}$ & GCC CTG TGG GGT GTA CAC & NM174557-AJ223170 & 340 \\
\hline & $\mathrm{r}$ & TGC AGC TCA CTC TGG CAG & & \\
\hline \multirow[t]{2}{*}{$I G F B P-5$} & $\mathrm{f}$ & CGG CAG GAC GAG GAG AAG & NM001105327-DQ079593 & 187 \\
\hline & $\mathrm{r}$ & AGA TGC GGG TGT GCT TGG & & \\
\hline \multirow[t]{2}{*}{$I G F B P-6$} & $\mathrm{f}$ & AGA AAG AGG ATT TGC CTT TGC & Plath-Gabler et al. (2001) & 324 \\
\hline & $\mathrm{r}$ & TCC GGT AGA AGC CCC TAT G & & \\
\hline \multirow[t]{2}{*}{$A L S$} & $\mathrm{f}$ & CAA CTT СТC СТC CAT СCC & DQ444712 & 151 \\
\hline & $\mathrm{r}$ & CAG ACG ATT GTG CTC CAG & & \\
\hline \multirow[t]{2}{*}{$I G F-1 R$} & $\mathrm{f}$ & TTA AAA TGG CCA GAA CCT GAG & X54980-FJ032309 & 313 \\
\hline & $\mathrm{r}$ & CAT CAT AAC CAA GCC TCC CAC & & \\
\hline \multirow[t]{2}{*}{ GHR } & $\mathrm{f}$ & GGA ACC ACC ACC CAA TAC AG & EU178741 & 169 \\
\hline & $\mathrm{r}$ & TCT CAC ACG CAC TTC ATA CTC & & \\
\hline \multirow[t]{2}{*}{ GHR-1A } & $\mathrm{f}$ & CAC CAT ATT CCT СCT CCA AC & AY775296 & 204 \\
\hline & $\mathrm{r}$ & GCT GCC AGA GAT CCA TAC C & & \\
\hline \multirow[t]{2}{*}{ GHR-1B } & $\mathrm{f}$ & GAA CCG CGC TCT CTC TCC & AF046861 & 62 \\
\hline & $\mathrm{r}$ & GCT GCC AGA GAT CCA TAC C & & \\
\hline \multirow[t]{2}{*}{ GHR-1C } & $\mathrm{f}$ & GAA AAC GAC CAG GCT CAA AG & AF 036290 & 82 \\
\hline & $\mathrm{r}$ & GCT GCC AGA GAT CCA TAC C & & \\
\hline \multirow[t]{2}{*}{ GHR-1C3 } & $\mathrm{f}$ & CTG CTG AGC GAG GAG AGG & AF085281 & 123 \\
\hline & $\mathrm{r}$ & GCA CAA ACG CAC AAA GGG & & \\
\hline \multirow[t]{2}{*}{ GHR-1D } & $\mathrm{f}$ & GAA CCG CGC TCT CTC TCC & AF036292 & 117 \\
\hline & $\mathrm{r}$ & ATC TCC ACC CAC CTC AGC & & \\
\hline \multirow[t]{2}{*}{ GHR-1F } & $\mathrm{f}$ & TCA CGA GAA GAG ATA CAC AGG & AF036294 & 117 \\
\hline & $\mathrm{r}$ & GCT GCC AGA GAT CCA TAC C & & \\
\hline \multirow[t]{2}{*}{ GHR-1G } & $\mathrm{f}$ & CTC ACT TAT TGC CTG ACC CAC & AF036296 & 76 \\
\hline & $\mathrm{r}$ & GCT GCC AGA GAT CCA TAC C & & \\
\hline \multirow[t]{2}{*}{ GHR-1H } & $\mathrm{f}$ & CTT CCA GGC TAG AGA ACA GTC & AF036297 & 146 \\
\hline & $\mathrm{r}$ & GCT GCC AGA GAT CCA TAC C & & \\
\hline \multirow[t]{2}{*}{ GHR-1I } & $\mathrm{f}$ & GTC CCA TCC AGT TAA ATG AAG G & AF326349 & 151 \\
\hline & $\mathrm{r}$ & GCA TTT GTA GTA AGT AAC TGA TTC & & \\
\hline
\end{tabular}

changes in the proteomic profile of white blood cells stimulated with GH (Chung et al., 2009).

The best reference genes must be chosen on the basis of their stability, their lack of responsiveness to the pharmacological treatment and of the expression level, which should be reasonably close to that of the target genes (Robinson et al., 2007). Out of the eight candidate reference genes identified in a previous study (Castigliego et al., 2010b), HMBS, EEFIA2 and SF3A1 were chosen because they represented the best combination of stability and expression level. In fact, the geometric mean of their $\mathrm{Ct}$ was $<10$ cycles from the $\mathrm{Ct}$ of the most abundantly expressed gene and from the $\mathrm{Ct}$ of the less expressed gene that has been taken into consideration in this study.

\section{Influence of exogenous GH on gene expression}

To our knowledge, there are no specific studies on somatotropic gene expression in buffalo leucocytes, and most of the attention that has been paid to the influence of GH treatment 


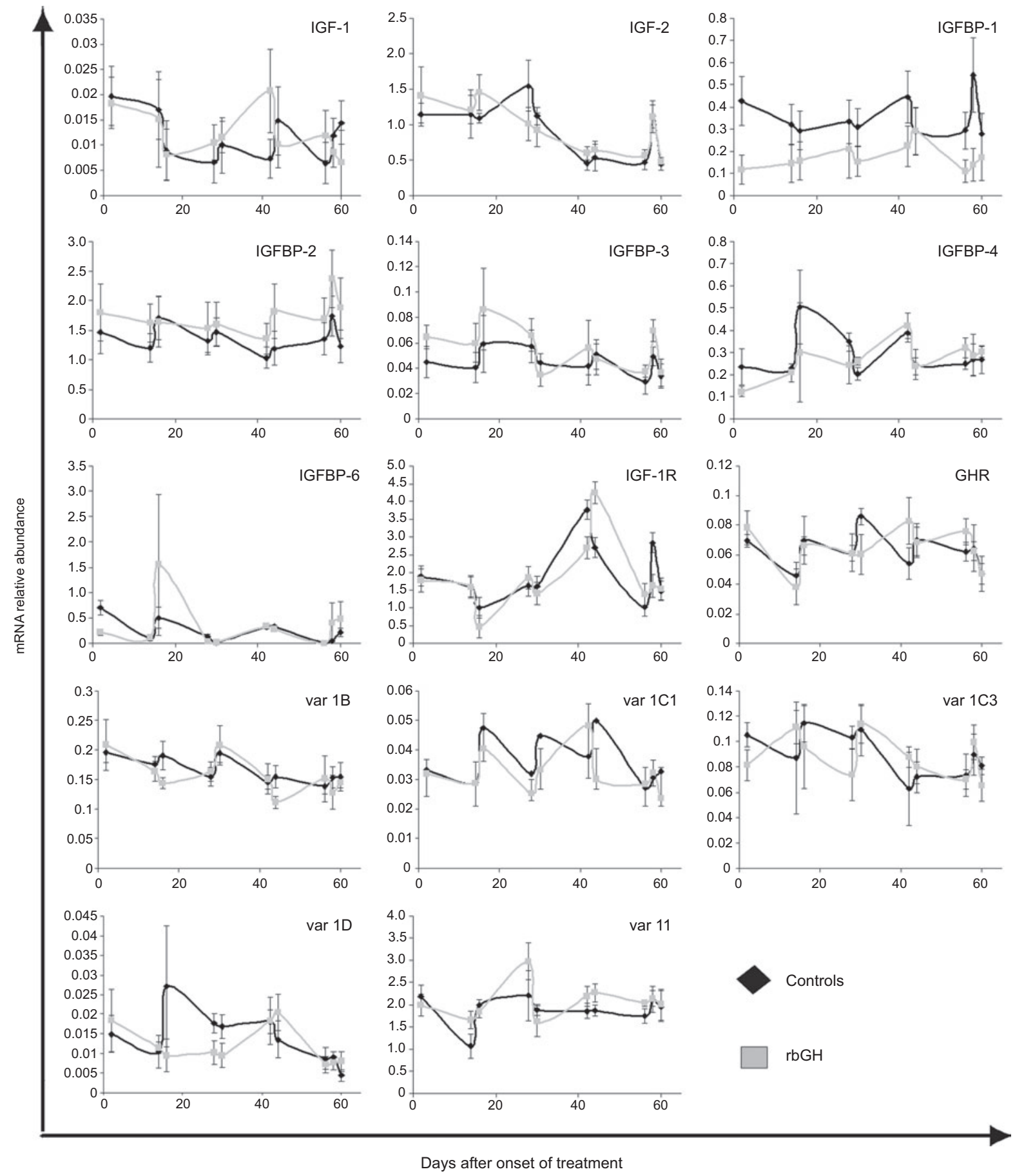

Figure 1 Variation of mRNA relative abundance for each analysed gene during the period of rbGH administration. rbGH was injected on days $2,14,16,28,30,42,44,56,58$ and 70 after the beginning of the treatment.

on gene expression has focused on other matrices. The importance of investigating individual organs or tissues is related to their different response to environmental changes as a consequence of specific regulation mechanisms in each tissue, as highlighted by studies on many animal species, including bovines (Lucy et al., 1995; Kirby et al., 1996). Recently, we performed a study on somatotropic gene expression in the skeletal muscle of GH-treated cows. It was observed that $G H R$ showed a slight tendency to be down-regulated on day 2 after GH injection (Castigliego et al., 2010a). GHR has also been identified in lymphocytes and macrophages, and $\mathrm{GH}$ has been shown to stimulate their proliferation in vitro (Clark, 1997; Jeay et al., 2002). On the contrary, in this study, exogenous $\mathrm{GH}$ did not induce any alteration in GHR expression (Figure 2, Table 2). The low basal levels of GHR mRNA could reflect a minor role in regulation of somatotropic axis mechanisms 
Table 2 Summary of statistical analysis on the effect of rbGH administration on gene expression.

\begin{tabular}{|c|c|c|c|c|c|c|c|c|c|}
\hline & \multicolumn{6}{|c|}{ Scheirer-Ray-Hare } & \multirow{2}{*}{\multicolumn{2}{|c|}{$\begin{array}{c}\text { Wilcoxon } \\
\text { Days 2-14 }\end{array}$}} & \multirow{3}{*}{ 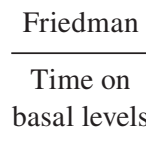 } \\
\hline & \multicolumn{3}{|c|}{ Day 2} & \multicolumn{3}{|c|}{ Day 14} & & & \\
\hline & $\operatorname{Tr}$ & Time & Int & $\operatorname{Tr}$ & Time & Int & $\mathrm{T}$ & $\mathrm{C}$ & \\
\hline$G H R$ & ns & ns & ns & ns & $p<0.05$ & ns & ns & ns & ns \\
\hline GHR-1B & ns & $p<0.05$ & ns & ns & ns & ns & ns & ns & $p<0.001$ \\
\hline GHR-1C1 & $\mathrm{ns}$ & $\mathrm{ns}$ & $\mathrm{ns}$ & ns & ns & ns & $p<0.05$ & ns & ns \\
\hline GHR-1C3 & $\mathrm{ns}$ & ns & $\mathrm{ns}$ & ns & ns & ns & ns & ns & $p<0.05$ \\
\hline GHR-1D & ns & ns & ns & ns & $p<0.01$ & ns & ns & ns & $\mathrm{ns}$ \\
\hline GHR-1I & ns & ns & ns & ns & $p<0.01$ & ns & ns & ns & $p<0.05$ \\
\hline$I G F-1$ & $\mathrm{~ns}$ & $\mathrm{~ns}$ & ns & ns & ns & ns & ns & ns & ns \\
\hline$I G F-2$ & $\mathrm{~ns}$ & $p<0.05$ & ns & ns & $p<0.001$ & ns & $p<0.05$ & ns & $p<0.001$ \\
\hline$I G F-1 R$ & ns & $p<0.001$ & ns & ns & $p<0.05$ & ns & ns & ns & $p<0.01$ \\
\hline$I G F B P-1$ & $p<0.001$ & ns & $\mathrm{ns}$ & $p<0.01$ & $\mathrm{~ns}$ & ns & ns & ns & $\mathrm{ns}$ \\
\hline$I G F B P-2$ & ns & ns & ns & $\mathrm{ns}$ & ns & ns & ns & ns & $p<0.05$ \\
\hline$I G F B P-3$ & ns & $\mathrm{ns}$ & ns & ns & ns & ns & ns & ns & ns \\
\hline$I G F B P-4$ & $\mathrm{~ns}$ & $p<0.05$ & ns & ns & $p<0.05$ & ns & ns & ns & ns \\
\hline$I G F B P-6$ & $\mathrm{~ns}$ & $p<0.001$ & ns & ns & $p<0.001$ & ns & $\mathrm{ns}$ & ns & $p<0.001$ \\
\hline
\end{tabular}

Effect of treatment (Tr), of time and of their interaction (Int) on the expression of the analysed genes on day 2 and day 14 after rbGH injection, using Scheirer-Ray-Hare's test; comparison of expression levels on day 2 and day 14 for each gene, using Wilcoxon's test; influence of time on the basic gene expression levels (calculated on controls), using Friedman's test; T, treated buffaloes; C, controls; ns, not significant.

in leucocytes, especially if compared with the abundance of IGF-1R mRNA. However, the higher levels of the mRNA of some GHR variants with respect to cds-GHR mRNA are not a straightforward occurrence. From one point of view, it cannot be assured, based on the current state of the art, that the sum of the mRNA of all the variants corresponds to that of cdsGHR, even though in a previous study on muscle this equation seemed to be approximately satisfied (Castigliego et al., 2010a). Moreover, it is not possible to exclude the occurrence of an alternative splicing, which lowers the total amount of cds-GHR mRNA that includes part of the sequence targeted by our primers (reviewed in Edens and Talamantes, 1998). However, it might be that primer sequences had one key mismatch on the gene sequence that was never recorded and which determines a slowdown in the first phases of amplification, when only cDNA is present in the mix. This does not influence the calculated amplification efficiency if measured during the log phase, as done by the software associated to the thermocycler used in this study, but can introduce an error in the calculation of the absolute quantity of mRNA. However, it is not important for the main aim of this work, which involves a comparative study between GH-treated and non-treated animals.
$\mathrm{GH}$ has been shown to influence the expression of variant $1 \mathrm{~A}$ in the liver of cows (Jiang et al., 2007). Because rbGH administration might provoke a rearrangement in the expression pattern of the GHR variants in some cell types, we investigated the potential GH-induced variation in expression of the $5^{\prime}$-UTR GHR variants. GHR 5'-UTR 1A, $1 \mathrm{~B}$ and $1 \mathrm{C}$ have been shown to be the variants mainly expressed in bovine liver or muscle and are presumed to play a decisive role in regulating the expression of the GHR protein (Lucy et al., 1998). Other variants (1D, 1E, 1F, 1G, 1H and 1I) have been supposed to give more significant contributions only in particular physiological conditions or in particular cell types (Jiang and Lucy, 2001). Variants 1C1, 1C2 and 1C3 are produced from exon $1 \mathrm{C}$, because of different initiation points for transcription (Jiang et al., 1999). Variants 1D consists of a 182-bp region identical to the $5^{\prime}$-UTR variant $1 \mathrm{C} 2$ and $1 \mathrm{C} 3$ and a 43-bp region identical to variant $1 \mathrm{~B} 1$ and $1 \mathrm{~B} 2$. The variant $1 \mathrm{I}$ is not related to the variants $1 \mathrm{~A}, 1 \mathrm{~B}$ and $1 \mathrm{C}$ in bovines (Jiang and Lucy, 2001). In the present study, GHR expression was found to correlate with all its $5^{\prime}$-UTR variants, at different levels of significance (Table 3). Strong correlation was only found with variant $1 \mathrm{C} 3(p<0.001)$. This evidence may suggest a major association between the cds-GHR, which

Table 3 Spearman's partial correlation of the expression levels for GHR and GHR 5'-UTR variants.

\begin{tabular}{|c|c|c|c|c|c|c|}
\hline & GHR-1B & GHR-1C1 & GHR-1C3 & GHR-1D & GHR-1I & $G H R$ \\
\hline Serum GH & ns & $\mathrm{ns}$ & ns & ns & ns & $p<0.05$ \\
\hline Serum IGF-1 & $p<0.01$ & ns & ns & $p<0.05$ & ns & ns \\
\hline GHR-1B & & ns & $p<0.01$ & ns & ns & $p<0.01$ \\
\hline GHR-1C1 & & & $p<0.01$ & ns & ns & $p<0.05$ \\
\hline GHR-1C3 & & & & $p<0.05$ & ns & $p<0.001$ \\
\hline GHR-1D & & & & & ns & $p<0.01$ \\
\hline GHR-1I & & & & & & $p<0.05$ \\
\hline
\end{tabular}


Table 4 Spearman's partial correlation of the expression level for each analysed gene pair (excluding GHR 5'-UTR variants) and circulating hormone concentrations.

\begin{tabular}{|c|c|c|c|c|c|c|c|c|c|}
\hline & $I G F-1$ & $I G F-2$ & $I G F-1 R$ & $G H R$ & $I G F B P-1$ & $I G F B P-2$ & $I G F B P-3$ & $I G F B P-4$ & $I G F B P-6$ \\
\hline Serum GH & ns & $p<0.05$ & ns & $p<0.05$ & ns & ns & ns & $p<0.01$ & ns \\
\hline Serum IGF-1 & ns & $\mathrm{ns}$ & $\mathrm{ns}$ & ns & ns & ns & ns & ns & ns \\
\hline$I G F-1$ & & ns & ns & ns & ns & $p<0.01$ & ns & ns & ns \\
\hline$I G F-2$ & & & ns & $p<0.01$ & $p<0.05$ & ns & $p<0.001$ & ns & ns \\
\hline$I G F-1 R$ & & & & $p<0.05$ & ns & ns & ns & ns & ns \\
\hline GHR & & & & & ns & ns & $\mathrm{ns}$ & ns & ns \\
\hline$I G F B P-1$ & & & & & & $p<0.001$ & $\mathrm{~ns}$ & $p<0.05$ & ns \\
\hline$I G F B P-2$ & & & & & & & ns & ns & ns \\
\hline$I G F B P-3$ & & & & & & & & ns & ns \\
\hline$I G F B P-4$ & & & & & & & & & $p<0.05$ \\
\hline
\end{tabular}

includes exons 6 and 7, and this variant. Except for variant 1I, whose expression level was found to be markedly higher with respect to the other variants, $1 \mathrm{~B}, 1 \mathrm{C} 1,1 \mathrm{C} 3$ and $1 \mathrm{D}$ showed a low level of expression in leucocytes of both treated buffaloes and controls (Figure 3). A similar condition has also been observed in bovine spleen by Jiang and Lucy (2001). Only 1C1 showed a slight significant decrement of expression $(p<0.05)$ on day 2 compared with day 14 in the treated group, but not in the controls. This could be related to a response to exogenous $\mathrm{GH}$, but its magnitude was not high enough to be considered as a biomarker. In the previous study on bovine
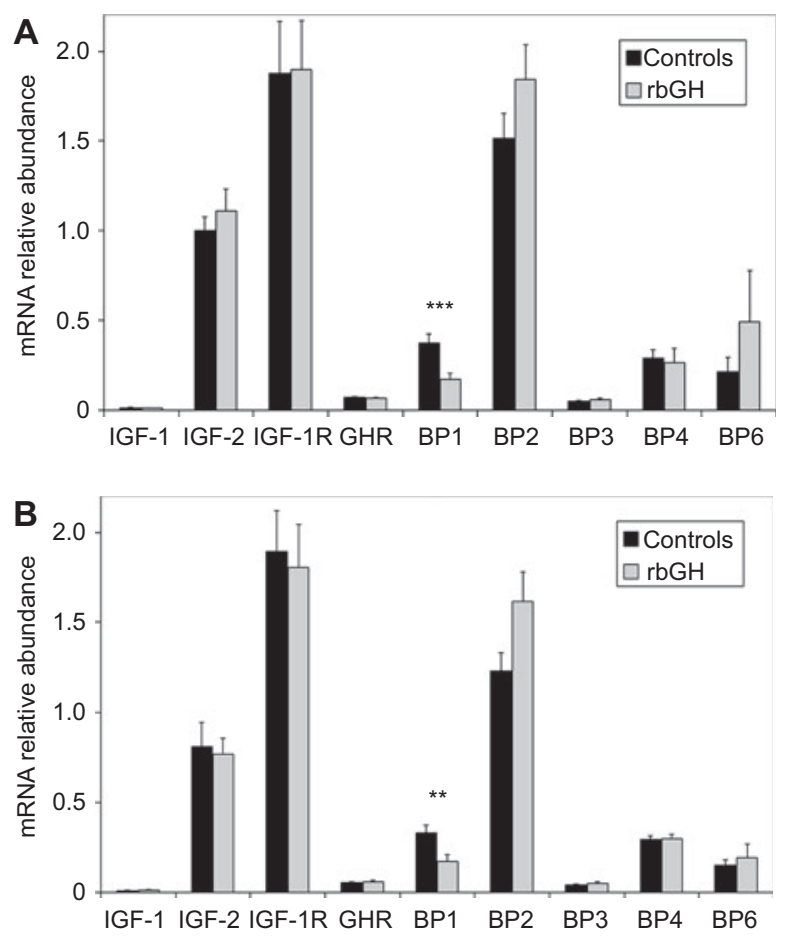

Figure 2 Relative expression levels of the analysed genes (excluding GHR 5'-UTR variants).

Overall comparison between treated animals and controls on day 2 (A) and on day 14 (B). $* * p<0.01$; ***p $<0.001$. skeletal muscle, an increase in expression was observed for GHR 5'-UTR variant 1I on day 14 (Castigliego et al., 2010a). Taken together, these results indicate that GH treatment had no relevant influence on the expression of GHR variants in leucocytes.

IGF-1 is a critical lactogenesis factor. Although the liver is the main endocrine source of IGF-1, its secretion has been observed in most tissues of the body. However, if the liver production of this hormone has been demonstrated to be under the control of circulating GH (Mathews et al., 1986), the expression of $I G F-1$ gene at the tissue level can be
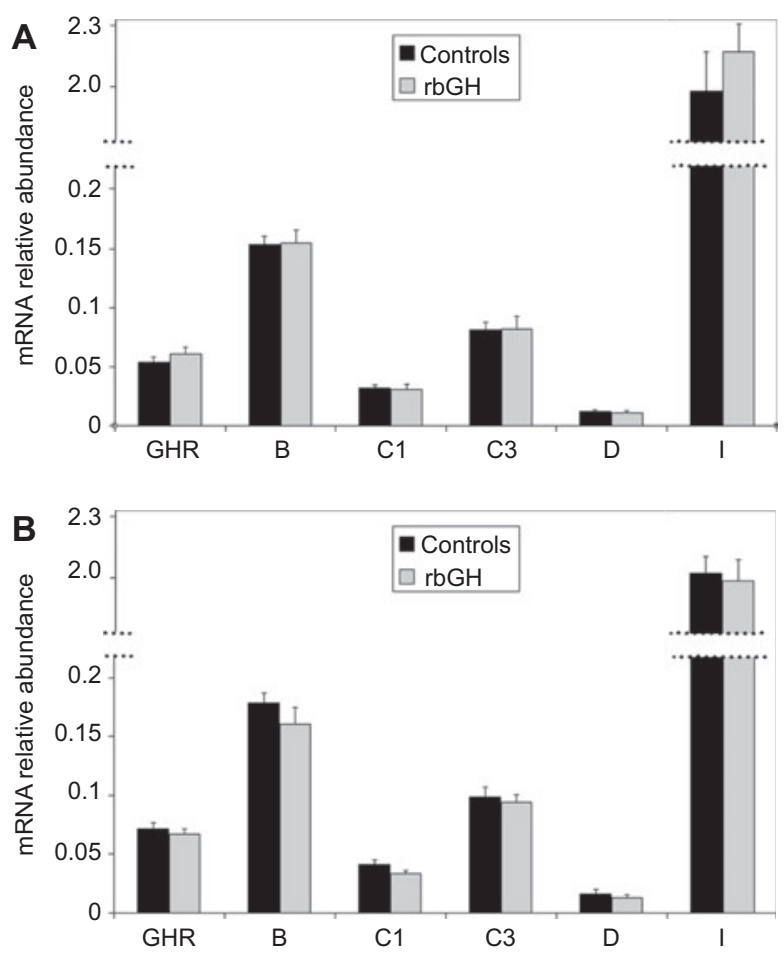

Figure 3 Relative expression levels of the GHR 5'-UTR variants. Overall comparison between treated animals and controls on day 2 (A) and on day 14 (B). 
independent from it and undergoes different or more incisive mechanisms of regulation. In fact, the lack of influence of $\mathrm{GH}$ on local $I G F-1$ expression has been observed in a number of tissues or organs, such as the mammary gland of cows (Sharma et al., 1994) and ewes (Bassett et al., 1998), and the muscle (Castigliego et al., 2010a) and reproductive tissues of cows (Lucy et al., 1995; Kirby et al., 1996). Although many effects of GH are also mediated by IGF-1 and some leucocytes also express IGF-1 (Kelley et al., 2007), we found a very low level of $I G F-1$ expression and no significant differences between treated buffaloes and controls (Figure 2, Table 2), despite the sharp increase in GH and IGF-1 protein in blood after rbGH treatment, indicating a minor role of $I G F-1$ gene in regulating local mechanisms.

On the other hand, the expression level of $I G F-2$ was noticeably higher than that of $I G F-1$. This agreed with similar observations in other tissues of cattle (Georgieva et al., 2003). However, we did not find significant differences between the treated and the control groups during the five cycles of treatment (Figure 2, Table 2). The overall data on the variations for paired samples throughout the period of the study revealed a slight but significant $(p<0.05)$ underexpression of $I G F-2$ on day 2 compared with day 14 in the treated group, but not in the controls. Moreover, the expression level of $I G F-2$ revealed a good correlation $(p<0.001)$ with IGFBP-3 (Table 4). Even though these data do not demonstrate any co-expression between the two genes, they may suggest a common response to environmental or specific factors.

The bioavailability of free IGFs is regulated by the IGFBPs to competitively limit access to IGF-1R (Baxter, 2000). The pattern of production of IGFBPs is specific for different cell types. In human peripheral blood mononuclear cells, secretion of IGFBP-2, -3 and -4 was reported to be independent of GH (Auernhammer et al., 2002). In this study, we observed no expression of $I G F B P-5$, and a low expression level of $I G F B P-3$, whereas $I G F B P-1,-4$ and -6 were expressed at moderate levels. On the contrary, IGFBP-2 mRNA abundance was several fold higher than that of the other binding proteins (Figure 2), suggesting that, during mid lactation, the leucocyte contribution to the regulatory mechanisms of somatotropic axis in the bloodstream mediated by $I G F B P-2$ may be of a certain importance. Even though IGFBP-2 seems to be metabolically modulated (Wheatcroft and Kearney, 2009), $\mathrm{GH}$ treatment did not produce a significant effect on $I G F B P-2$ expression.

IGFBP-3 and -5 play an important role in binding most of the circulating IGFs to increase their half-life or to facilitate their distribution between the vascular and extravascular systems (Guler et al., 2008). The low level of expression of IGFBP-3 suggested that other tissues or organs, such as the liver, rather than blood, are mainly involved in the regulation of IGF-1 half-life, through the production of dedicated binding proteins. Furthermore, IGFBP-5 was previously shown to be regulated by serum $\mathrm{GH}$ in the skeletal muscle. It has been suggested that it probably acts as a local factor to compete with receptors in binding IGF-1, thus limiting or modulating its stimulating effect on tissues (Castigliego et al., 2010a).
We think that the absence of IGFBP-5 expression in leucocytes may be related to its specific local role since what is secreted by the blood cells cannot be localised to a restricted environment.

The only binding protein gene that has been shown to respond to the rbGH administration was IGFBP-1, which was significantly under-expressed in treated animals both on day $2(p<0.001)$ and on day $14(p<0.01)$ (Figure 1, Table 2$)$. A number of studies indicated that IGFBP-1 is a dynamic regulator of IGF bioactivity in vivo, which modulates the shortterm bioavailability of IGF-1 in response to fasting or feeding (Jones and Clemmons, 1995) and inhibits IGF-dependent cellular growth and differentiation (Kelley et al., 1996). IGFBP-1 also exerts IGF-independent effects, such as stimulating cell adhesion and migration after binding to the $\alpha_{5} \beta_{1}$ integrins (Jones et al., 1993; Gleeson et al., 2001). Variations in circulating insulin are the principal mechanism by which IGFBP-1 concentrations are regulated (Yki-Jarvinen et al., 1995). This association coupled to the modulatory action of IGFBP-1 on IGF-1 contributes to the maintenance of glucose homeostasis (reviewed in Wheatcroft and Kearney, 2009). Even though most of circulating IGFBP-1 derives from the liver, a contribution may be carried by other tissues, such as blood. As well as in the liver, inhibition of IGFBP-1 expression in leucocytes may be due to the inhibitory action of GH (Seneviratne et al., 1990; Gronowski and Rotwein, 1995) or of insulin, whose plasma levels have often been reported to increase as a consequence of GH treatment in lactating cows (Hodate et al., 1991; VanderKooi et al., 1995; Holzer et al., 1999). However, this last hypothesis cannot be supported by a direct measurement of plasma insulin in the buffaloes involved in this study.

Finally, multivariate discriminant analysis (MDA) enabled us to reach, at best, a level of $12 \%$ misclassification of samples, divided equally among treated animals and controls. Therefore, this method of discrimination cannot guarantee the absence of both false-negative and false-positive outcomes.

In conclusion, gene expression analysis of peripheral blood leucocytes of buffaloes after treatment with rbGH revealed a slight change in the expression level of the somatotropic axis genes. This can be determined by an intrinsic resistance, as the result of different signals, whose complex synergy may be due to the peculiar biochemistry of certain cell population or to the expression of a particular physiological state. This would produce a sort of internal pathway 'homeostasis', which would attenuate the GH overstimulus.

Only $I G F B P-1$ was shown to respond markedly to exogenous GH stimulus, despite the fact that it cannot be considered alone as a reliable biomarker to reveal a hormonal administration. Therefore, also in the light of other promising approaches for research of gene expression biomarkers, there is a need to perform further investigation on other candidate genes, whose overall response to $\mathrm{rbGH}$ may provide reliable patterns to discriminate treated animals. This can be obtained by microarray analyses, which, even though expensive, are characterised by a very high throughput and may give important hints for better focused and precise analysis using realtime PCR. 


\section{Materials and methods}

\section{Experimental design, rbGH treatment, sample collection and blood processing}

The study was conducted over a period of 10 weeks on lactating multiparous Mediterranean buffaloes (Bubalus bubalis). Ten animals with a similar milk yield $(8.93 \pm 0.65 \mathrm{l} / \mathrm{d})$ were selected from the dairy herd of the Institute of Experimental Zootechny of Monterotondo (Rome, Italy). Their age ranged from 4 to 7 years and their weight was $705 \pm 75 \mathrm{~kg}$.

The animals were housed in a free open-stall barn, with concrete floor and a roof-covered area for resting and feeding and access to an outdoor lot with natural ground. They were fed a mixed diet (corn silage, alfalfa hay, maize flour, soybean meal) ad libitum twice daily, with free access to fresh water. Animals were kept under veterinary observation throughout the whole experimentation period. They underwent an ordinary health check once a week and were managed during the study in compliance with the Italian law on animal protection for experimental and other scientific purposes (D.L. No. 116/1992).

The animals were allotted randomly to two groups ( $\mathrm{n}=5 /$ group). One group was given the rbGH treatment and the other served as control. Treatment was performed supplementing a sustained release formulation of rbGH (Boostin; LG Life Sciences, Seoul, Korea), 500 $\mathrm{mg} / \mathrm{dose}$ in $2 \mathrm{ml}$, as subcutaneous injections in the tail head area, every 14 days, after the 9 th week post partum ( $68 \pm 3$ days after parturition) for a total period of five cycles of injections. A saline solution $(0.9 \% \mathrm{NaCl})$ was administrated to the controls.

To assess whether rbGH treatment was effective, the milk yield of each buffalo was measured on day 5 of each cycle. Blood samples were collected before the first meal of days 2 and 14 after each rbGH injection by jugular venipuncture in vacutainer tubes with EDTA, and immediately processed. Day 14 was the last day before a new injection of rbGH. Blood samples were submitted to RNA extraction and to cell count for a health check.

\section{Extraction of the RNA and reverse transcription-PCR}

The leucocyte total RNA was extracted using a PerfectPure RNA Blood Kit (5 Prime, Gaithersburg, MD, USA) according to the manufacturer's instructions. RNA was then frozen at $-80^{\circ} \mathrm{C}$ and sent in dry ice to another laboratory for further processing. The amount of RNA extracted was estimated using a NanoDrop ND-1000 spectrophotometer (NanoDrop Technologies Inc., Wilmington, DE, USA) by measuring the optical density (OD) at $260 \mathrm{~nm}$. Its purity was evaluated as the ratios $\mathrm{OD}_{260} / \mathrm{OD}_{280}$ and $\mathrm{OD}_{260} / \mathrm{OD}_{230}$. RNA integrity was assessed by denaturing $1 \% \mathrm{w} / \mathrm{v}$ agarose gel electrophoresis. Then $0.5 \mu \mathrm{g}$ of extracted RNA was immediately treated with DNAse and reverse transcribed into cDNA using a QuantiTect Rev. Transcription Kit (Qiagen, Hilden, Germany), according to the manufacturer's instructions, in a final volume of $30 \mu \mathrm{l}$. The cDNA obtained was stored at $-20^{\circ} \mathrm{C}$ until the PCR. Tests to ascertain the absence of genomic DNA contamination were produced by performing retro-transcriptions without reverse transcriptase, and non-reverse-transcribed samples were included in the PCR reaction.

\section{Primer design}

Primers were mainly designed in a previous study (Castigliego et al., 2010a) on the basis of the bovine sequence deposited in GenBank using Beacon Designer 5.01 (Premier Biosoft International, Palo Alto, CA, USA), checked on buffalo sequences, when available, and corrected (Table 1). Amplicons were planned to span at least two exons of the coding sequence, with the exception of $A L S$, made by only two exons, of which the first is too short for the hosting of a forward primer with the characteristics required. For most of the GHR $5^{\prime}$-UTR variants, a common reverse primer was designed that anneals on the first common exon (exon 2). Exceptions included variants $1 \mathrm{C} 3,1 \mathrm{D}, 1 \mathrm{E}$ and $1 \mathrm{I}$ for which a specific reverse primer was created. For 1C3 and 1I, both primers stand on the same exon sequence, while primers for $1 \mathrm{D}$ are placed on very distant sequences on genomic DNA. No suitable primers were found for $1 \mathrm{C} 2$, which is why it was excluded from the analysis.

Hydroxymethylbilane synthase $(H M B S)$, eukaryotic translation elongation factor $1 \alpha 2$ (EEFIA2) and splicing factor 3 subunit 1 (SF3A1) were used as reference genes, according to a previously performed pilot study (Castigliego et al., 2010b).

Table 1 shows the primer sequences, codes of the deposited sequences used for the primer design and the amplicon length.

\section{Real-time PCR}

The cDNA obtained was amplified by real-time PCR in a RotorGene 6000 thermocycler (Corbett Research, Sydney, Australia). Each reaction was performed in $100-\mu 1$ tubes, and the working solution was made up of $5 \mu \mathrm{l}$ of a premixed solution (QuantiTect SYBR Green PCR Kit, Qiagen), $1.5 \mu \mathrm{l}$ of the premixed forward and reverse primers (final concentration of $0.2 \mu \mathrm{M}$ ), $1 \mu \mathrm{l}$ of cDNA solution and 2.5 $\mu 1$ of water. For each sample, a blank reaction without a template was included. All the amplifications were produced according to a cycling protocol previously adapted for the ensemble analysis of the eight selected genes: $15 \mathrm{~min}$ at $95^{\circ} \mathrm{C}, 40$ cycles of $15 \mathrm{~s}$ at $94^{\circ} \mathrm{C}, 30 \mathrm{~s}$ at $53^{\circ} \mathrm{C}, 30 \mathrm{~s}$ at $72^{\circ} \mathrm{C}$, and a final extension of $5 \mathrm{~min}$ at $72^{\circ} \mathrm{C}$. At the end of each run, a melting curve analysis $\left(95^{\circ} \mathrm{C}\right.$ for $15 \mathrm{~s}, 60^{\circ} \mathrm{C}$ for $1 \mathrm{~min}$, increase of $0.5^{\circ} \mathrm{C} / 5 \mathrm{~s}$ until $95^{\circ} \mathrm{C}$ ) was performed to assess the amplification specificity. To verify the correspondence of each PCR product with the known sequences stored in the databases, preliminary amplifications were performed on leucocytes and other buffalo tissues, and DNA products were both checked by electrophoresis and sequenced on commission by BMR Genomics (Padua, Italy).

Data analysis was carried out using an efficiency correction model. In brief, we used the following formula to calculate the relative expression $(R)$ of each target gene:

$R=\left(E_{\text {ref1 }}{ }^{{ }^{C P r e f 1}} \times E_{\text {ref2 }}{ }^{\mathrm{CP} \text { ref2 }} \times E_{\text {ref3 }}{ }^{\mathrm{CP} \text { ref3 } 3}\right)^{1 / 3} \div E_{\text {target }}{ }^{\mathrm{CP} \text { target }}$

where $\left(E_{\text {refl }}{ }^{{ }^{C P} \text { ref1 }} \times E_{\text {ref2 }}{ }^{\mathrm{CP} \text { ref2 }} \times E_{\text {ref3 }}{ }^{\mathrm{CP} \text { ref3 }}\right)^{1 / 3}$ represents the geometrical mean of the efficiency corrected values of the three reference genes, and $E_{\text {target }}$ CP target represents the efficiency corrected value of the target gene. Each $E^{\mathrm{CP}}$ is in turn the product of the geometrical mean of the triplicates.

$E$ represents the mean of the efficiencies for a single gene of all the samples, and $\mathrm{CP}$ is the crossing point. Efficiency was calculated using the thermocycler-associated software, for each gene in each run, according to the equation $E=\left[10^{(-1 / M)}\right]-1$, where $M$ is the slope of the amplification curve in the exponential phase.

\section{Serum GH and IGF-1}

The total amounts of circulating bovine GH and IGF-1 were measured by a sandwich ELISA as described previously, where full results on hormone levels were presented in full (Castigliego et al., 2011). Here, we only use values for correlation analysis.

\section{Statistical analyses}

To assess the equality of variance between the treated and the control group, Levene's test was used. Since dissimilar variances were 
found for a number of genes, a non-parametric multiway ANOVA (Scheirer-Ray-Hare extension of the Kruskal-Wallis test) was used to assess the effect of treatment, of time on treatment and their interaction on milk yield on day 7; hormone concentration and gene expression levels, both on day 2 and on day 14. A comparison was also performed between day 2 and day 14 after each injection in treated animals and controls, using the Wilcoxon test for paired samples.

To evaluate the effect of time on the basal level of the analysed parameters, Friedman's ANOVA by ranks was performed on nontreated animals.

Spearman's rank partial correlation was used to assess the relation between every possible combination of paired genes and between genes and circulating hormones.

Values are reported as means \pm SEM. Differences were considered significant when $p$ was $<0.05$. Data were processed using PRISM version 5.01 (GraphPad Software Inc., San Diego, CA, USA) and JMP version 5.01 (SAS Institute Inc., Cary, NC, USA).

Finally, to investigate the multivariate response to GH administration, we adopted the MDA, which predicts which group $(Y)$ an observation belongs to, based on the characteristics of $p$ predictor $(X)$ variables. The multidimensionality of data is transformed by a specific algorithm to essentially two dimensions, which can be plotted. Different combinations of genes have been tried, based on the single contribution to the variability of data.

\section{Acknowledgements}

This work was supported by the Ministry of Health (Current Research Grant IZSLT17/07RC).

\section{References}

Auernhammer, C.J., Fottner, C., Engelhardt, D., Bidlingmaier, M., Strasburger, C.J., and Weber, M.M. (2002). Differential regulation of insulin-like growth factor-(IGF) I and IGF-binding protein (IGFBP) secretion by human peripheral blood mononuclear cells. Horm. Res. 57, 15-21.

Bassett, N.S., Currie, M.J., Breier, B.H., Klempt, M., Min, S.H., McCutcheon, S.N., MacKenzie, D.D.S., and Gluckman, P.D. (1998). The effects of ovine placental lactogen and bovine growth hormone on hepatic and mammary gene expression in lactating sheep. Growth Horm. IGF Res. 8, 439-446.

Bauman, D.E. (1992). Bovine somatotropin: review of an emerging animal technology. J. Dairy Sci. 75, 3432-3451.

Baxter, R.C. (2000). Insulin-like growth factor (IGF)-binding proteins: interactions with IGFs and intrinsic bioactivities. Am. J. Physiol. Endocrinol. Metab. 278, E967-E976.

Castigliego, L., Armani, A., Grifoni, G., Rosati, R., Mazzi, M., Gianfaldoni, D., and Guidi, A. (2010a). Effects of growth hormone treatment on the expression of somatotropic axis genes in the skeletal muscle of lactating Holstein cows. Domest. Anim. Endocrinol. 39, 40-53.

Castigliego, L., Armani, A., Li, X., Grifoni, G., Gianfaldoni, D., and Guidi, A. (2010b). Selecting reference genes in the white blood cells of buffalos treated with recombinant growth hormone. Anal. Biochem. 403, 120-122.

Castigliego, L., Li, X.N., Armani, A., Grifoni, G., Boselli, C., Rosati, R., Gianfaldoni, D., and Guidi, A. (2011). Hormone variations in serum and milk of buffalos (Bubalus bubalis) as potential indicators of treatment with recombinant bovine somatotropin. J. Dairy Res. 16, 1-9.
Chen, B.J., Deoliveira, D., Spasojevic, I., Sempowski, G.D., Jiang, C., Owzar, K., Wang, X., Gesty-Palmer, D., Cline, J.M., Bourland, J.D., et al. (2010). Growth hormone mitigates against lethal irradiation and enhances hematologic and immune recovery in mice and nonhuman primates. PLoS One 5, e11056.

Chung, L., Nelson, A.E., Ho, K.K.Y., and Baxter, R.C. (2009). Proteomic profiling of growth hormone-responsive proteins in human peripheral blood leukocytes. J. Clin. Endocrinol. Metab. 94, 3038-3043.

Clark, R. (1997). The somatogenic hormones and insulin-like growth factor-1: stimulators of lymphopoiesis and immune function. Endocr. Rev. 18, 157-179.

Daxenberger, A., Breier, B.H., and Sauerwein, H. (1998). Increased milk levels of insulin-like growth factor 1 (IGF-1) for the identification of bovine somatotropin (bST) treated cows. Analyst 123, 2429-2435.

Edens, A. and Talamantes, F. (1998). Alternative processing of growth hormone receptor transcripts. Endocr. Rev. 19, 559-582.

Fernández-Pérez, L., Nóvoa, J., Ståhlberg, N., Santana-Farré, R., Boronat, M., Marrero, D., Henriquez-Hernández, L., Norstedt, G., and Flores-Morales, A. (2010). The effect of in vivo growth hormone treatment on blood gene expression in adults with growth hormone deficiency reveals potential biomarkers to monitor growth hormone therapy. Clin. Endocrinol. 72, 800-806.

Georgieva, T.M., Georgiev, I.P., Ontsouka, E., Hammon, H.M., Pfaffl, M.W., and Blum, J.W. (2003). Abundance of message for insulin-like growth factors-I and -II and for receptors for growth hormone, insulin-like growth factors-I and -II, and insulin in the intestine and liver of pre- and full-term calves. J. Anim. Sci. 81, 2294-2300.

Gleeson, L.M., Chakraborty, C., McKinnon, T., and Lala, P.K. (2001). Insulin-like growth factor-binding protein 1 stimulates human trophoblast migration by signaling through $\alpha_{5} \beta_{1}$ integrin via mitogen-activated protein kinase pathway. J. Clin. Endocrinol. Metab. 86, 2484-2493.

Gronowski, A.M. and Rotwein, P. (1995). Rapid changes in gene expression after in vivo growth hormone treatment. Endocrinol. 136, 4741-4748.

Guler, H.P., Zapf, J., and Froesch, E.R. (2008). Short-term metabolic effects of recombinant human insulin-like growth factors-I in healthy adults. N. Engl. J. Med. 317, 137-140.

Helal, F.I.S. and Lasheen, M.A. (2008). The productive performance of Egyptian dairy buffaloes receiving biosynthetic bovine somatotropin (rbST) with or without monensin. Am. Eur. J. Agric. Environ. Sci. 3, 771-777.

Hodate, K., Ozawa, A., and Johke, T. (1991). Effect of a prolonged release formulation of recombinant bovine somatotropin on plasma concentrations of hormones and metabolites, and milk production in dairy cows. Endocrinol. Jpn. 38, 527-532.

Holzer, Z., Aharoni, Y., Brosh, A., Orlov, A., Veenhuizen, J.J., and Kasser, T.R. (1999). The effects of long-term administration of recombinant bovine somatotropin (Posilac) and Synovex on performance, plasma hormone and amino acid concentration, and muscle and subcutaneous fat fatty acid composition in HolsteinFriesian bull calves. J. Anim. Sci. 77, 1422-1430.

Jeay, S., Sonenshein, G.E., Postel-Vinay, M.C., Kelly, P.A., and Baixeras, E. (2002). Growth hormone can act as a cytokine controlling survival and proliferation of immune cells: new insights into signaling pathways. Mol. Cell. Endocrinol. 188, 1-7.

Jiang, H. and Lucy, M.C. (2001). Variants of the $5^{\prime}$-untranslated region of the bovine growth hormone receptor mRNA: isolation, expression and effects on translational efficiency. Gene 265, $45-53$. 
Jiang, H., Okamura, C.S., and Lucy, M.C. (1999). Isolation and characterization of a novel promoter for the bovine growth hormone receptor gene. J. Biol. Chem. 274, 7893-7900.

Jiang, H., Wang, Y., Wu, M., Gu, Z., Frank, S.J., and Torres-Diaz, R. (2007). Growth hormone stimulates hepatic expression of bovine growth hormone receptor messenger ribonucleic acid through signal transducer and activator of transcription 5 activation of a major growth hormone receptor gene promoter. Endocrinology 148, 3307-3315.

Jones, J.I. and Clemmons, D.R. (1995). Insulin-like growth factors and their binding proteins: biological actions. Endocr. Rev. 16, 3-34.

Jones, J.I., Gockerman, A., Busby, W.H., Wright, G., and Clemmons, D.R. (1993). Insulin-like growth factor binding protein 1 stimulates cell migration and binds to the $\alpha_{5} \beta_{1}$ integrin by means of its Arg-Gly-Asp sequence. Proc. Natl. Acad. Sci. USA 90, 10553-10557.

Kelley, K.M., Oh, Y., Gargosky, S.E., Gucev, Z., Matsumoto, T., Hwa, V., Ng, L., Simpson, D.M., and Rosenfeld, R.G. (1996). Insulin-like growth factor-binding proteins (IGFBPs) and their regulatory dynamics. Int. J. Biochem. Cell Biol. 28, 619-637.

Kelley, K.W., Weigent, D.A., and Kooijman, R. (2007). Protein hormones and immunity. Brain Behav. Immun. 21, 384-392.

Kirby, C.J., Thatcher, W.W., Collier, R., Simmen, F.A., and Lucy, M.C. (1996). Effects of growth hormone and pregnancy on expression of growth hormone receptor, insulin-like growth factor-I, and insulin-like growth factor binding protein-2 and -3 genes in bovine uterus, ovary, and oviduct. Biol. Reprod. 55, 996-1002.

Le Breton, M.H., Rochereau-Roulet, S., Pinel, G., Cesbron, N., and Le Bizec, B. (2009). Elimination kinetic of recombinant somatotropin in bovine. Anal. Chim. Acta 637, 121-127.

Lucy, M.C., Thatcher, W.W., Collier, R.J., Simmen, F.A., Ko, Y., Savio, J.D., and Badinga, L. (1995). Effects of somatotropin on the conceptus, uterus and ovary during maternal recognition of pregnancy in cattle. Domest. Anim. Endocrinol. 12, 72-82.

Lucy, M.C., Boyd, C.K., Koenigsfeld, A.T., and Okamura, C.S. (1998). Expression of somatotropin receptor messenger ribonucleic acid in bovine tissues. J. Dairy Sci. 81, 1889-1895.

Manfredi, R., Tumietto, F., Azzaroli, L., Zucchini, A., Chiodo, F., and Manfredi, G. (1994). Growth hormone (GH) and the immune system: impaired phagocytic function in children with idiopathic GH deficiency is corrected by treatment with biosynthetic GH. J. Pediatr. Endocrinol. 7, 245-251.

Mathews, L.S., Norstedt, G., and Palmiter, R.D. (1986). Regulation of insulin-like growth factor I gene expression by growth hormone. Proc. Natl. Acad. Sci. USA 83, 9343-9347.

McGuire, M.A., Vicini, J.L., Bauman, D.E., and Veenhuizen, J.J. (1992). Insulin-like growth factors and binding proteins in ruminants and their nutritional regulation. J. Anim. Sci. 70, 2901-2910.
Mitchell, C.J., Nelson, A.E., Cowley, M.J., Kaplan, W., Stone, G., Sutton, S.K., Lau, A., Lee, C.M.Y., and Ho, K.K.Y. (2009). Detection of growth hormone doping by gene expression profiling of peripheral blood. J. Clin. Endocrinol. Metab. 94, 4703-4709.

Pérez, R., Tupac-Yupanqui, I., and Dunner, S. (2008). Evaluation of suitable reference genes for gene expression studies in bovine muscular tissue. BMC Mol. Biol. 9, 79.

Plath-Gabler, A., Gabler, C., Sinowatz, F., Berisha, B., and Schams, D. (2001). The expression of the IGF family and GH receptor in the bovine mammary gland. J. Endocrinol. 168, 39-48.

Qin, Y. and Tian, Y.P. (2010). A microarray gene analysis of peripheral whole blood in normal adult male rats after long-term GH gene therapy. Cell. Mol. Biol. Lett. 15, 177-195

Renaville, R., Hammadi, M., and Portetelle, D. (2002). Role of the somatotropic axis in the mammalian metabolism. Domest. Anim. Endocrinol. 23, 351-360.

Riedmaier, I., Tichopad, A., Reiter, M., Pfaffl, M.W., and Meyer, H.H.D. (2009). Identification of potential gene expression biomarkers for the surveillance of anabolic agents in bovine blood cells. Anal. Chim. Acta 638, 106-113.

Robinson, T.L., Sutherland, I.A., and Sutherland, J. (2007). Validation of candidate bovine reference genes for use with real-time PCR. Vet. Immunol. Immunopathol. 115, 160-165.

Seneviratne, C., Luo, J.M., and Murphy, L.J. (1990). Transcriptional regulation of rat insulin-like growth factor-binding protein-1 expression by growth hormone. Mol. Endocrinol. 4, 1199-1204.

Sharma, B.K., VandeHaar, M.J., and Ames, N.K. (1994). Expression of insulin-like growth factor-I in cows at different stages of lactation and in late lactation cows treated with somatotropin. J. Dairy Sci. 77, 2232.

VanderKooi, W.K., VandeHaar, M.J., Sharma, B.K., Binelli, M., Tucker, H.A., Akers, R.M., and Moseley, W.M. (1995). Comparison of growth hormone-releasing factor and somatotropin: the somatotropic axis in lactating primiparous cows. J. Dairy Sci. 78, 2140-2149.

Welniak, L.A., Sun, R., and Murphy, W.J. (2002). The role of growth hormone in T-cell development and reconstitution. J. Leukoc. Biol. 71, 381-387.

Wheatcroft, S.B. and Kearney, M.T. (2009). IGF-dependent and IGF-independent actions of IGF-binding protein-1 and -2: implications for metabolic homeostasis. Trends Endocrinol. Metab. 20, 153-162.

Yki-Jarvinen, H., Mäkimattila, S., Utriainen, T., and Rutanen, E.M. (1995). Portal insulin concentrations rather than insulin sensitivity regulate serum sex hormone-binding globulin and insulinlike growth factor binding protein 1 in vivo. J. Clin. Endocrinol. Metab. 80, 3227-3232.

Received July 18, 2011; accepted September 15, 2011 